\title{
Attitudes of Students Taking Distance Education in Theology Undergraduate Education Program towards E-learning Management System
}

\author{
Murat Yalman*, Bülent Başaran, Selahattin Gönen \\ Ziya Gokalp Education Facility, Dicle University, Turkey
}

Copyright $(\mathrm{C} 2016$ by authors, all rights reserved. Authors agree that this article remains permanently open access under the terms of the Creative Commons Attribution License 4.0 International License

\begin{abstract}
Education is one of the biggest problems experienced by developing societies. Education is has an important place in individuals' lives since it allows them to prove themselves within their society and to maintain their future lives. Today, with the development of the Internet, education can be given via e-learning management systems designed on the web. E-learning is a type of education that can present information to its users via the Internet. In order to facilitate the use of e-learning systems and to make these systems more systematic, Learning Management Systems (LMSs) have appeared. LMSs are softwares that allow management of learning activities. During the application of e-learning management systems that can be designed in line with the desired curriculum, the feedback provided by students taking education via this platform play an important role in the success of the system. In this respect, the present study aimed at determining the attitudes of students attending Distance Education Theology Undergraduate Education Program at Dicle University towards e-learning. For this purpose, the five-point Likert-type scale of "Attitudes towards ICT skills and e-learning" developed by Haznedar [23] was applied to the students. The results of analysis of the data collected from the students participating in the study revealed no significant difference in relation to e-learning between the students' gender, years of computer use, weekly Internet use time, their preferences of types of education, their foreign language, their foreign language proficiency levels, and their learning motivation preferences. In the study, a significant difference was found in relation to e-learning between the participants' preferences of study methods.
\end{abstract}

Keywords E-learning, Distance Education

\section{Introduction}

Recent renovations in information technologies have led to great changes in the field of education. This situation has resulted in differences in definition, design and services of education (Ally, [1]). With the use and spread of the Internet and computer technologies in education, the concept of e-learning, which is totally different from face-to-face learning, has appeared.

E-learning is a type of learning which uses such computer network technologies as Internet and Extranet to provide its users with the necessary information (Cheng, [12]; Engelbrecht, [17]). Lee et al. [35], similarly, define e-learning system as an integrated information system which includes a variety of instructional material; audios, videos, and texts; messages via e-mail; online chat sessions; online discussions; forums; exams; and assignments. Recent technological developments have led to the development of innovative methods in learning and teaching the tendencies towards flexible learning in education (Benković, Dobrota, [6]). In this respect, e-learning systems have become an important part of modern university curricula and played an important role in supporting university students in terms of the education given via the Internet (Paechter et al. [40]). Related studies demonstrate that integration of online components into traditional classes develop communication, increase access to resources via the Internet and maximize students' satisfaction (Kaynama, Keesling, [29]). A number of factors in online environments have influence on students' satisfaction. Bolliger and Martindale [8] point out that there are three important factors such as the trainer, technology and interaction to increase students' satisfaction with e-learning. Drennan et al. [15] found that e-learning, a method of independent learning, could result in positive perceptions in student satisfaction. In addition, self-efficacy, social skills, the quality of the e-learning system, and multimedia-aided learning are among the most important structures for students' perceptions (Liaw, [36]). This demonstrates that there is a close relationship between students' satisfaction, successful teaching and quality of lessons (Peltier, Schibrowsky, Drago, [42]). Students' feedbacks regarding their levels of satisfaction are important 
to increase the overall quality of instructional activities, course contents and curricula (Bradford, Wyatt, [9]).

An important point in designing a successful e-learning system is related to the support services for students. Student support is any kind of support that could help meet students' needs before, during and after the education process (Thorpe, [54]). Student support services should be planned attentively to develop effective e-learning systems and designed in a way to cover all the academic, administrative, technical and social support needs of students. In order to establish successful academic environments for students taking e-learning education, various support services should be organized, and the necessary guidance should be provided to allow students make use of these services (Aoki, Pogroszewski, [4]). Activities designed for e-learning should be organized in line with the students' views as well as with the information provided by the students. Limited interaction between the faculty member and students is reported to be the most probable drawbacks of e-learning systems (Kaba, Güneş, Altıntaş, [26]). Gibson et al. [18] found in their study that students have negative viewpoints due to limited interaction. In this respect, interaction is a really important issue in e-learning systems, and while developing e-learning systems, it is important to pay enough attention to the dimension of interaction with students.

For a long time, the computer has been used as a tool to support education. With the spread of the Internet network technologies throughout the world, the Internet and computer are now increasingly used in education. Educational institutions using the Internet and computer initially as a support to face-to-face learning designed e-learning management systems and started to give education via these technologies. The advantages of e-learning, when compared to traditional learning, include removing the concepts of time and place from education, making students active and independent learners, and allowing cooperative learning (Yalman, Kutluca [57]).

In determining the success of e-learning programs, student satisfaction is another important factor. Satisfaction with e-learning has a relationship with interaction, course organization, support services and communication methods (Roberts, Irani, Telg, Lundy, [45]). Learner satisfaction has a relationship with the user-friendliness and effectiveness of Learning Management Systems, with flexibility, with interaction levels of students, with the importance given by the faculty member to interaction and with website use (Arbaugh, [5]). In order to facilitate the use of e-learning systems and to make these systems more systematic, Learning Management Systems (LMSs) have appeared. LMSs are softwares that allow management of learning activities. LMSs are environments basically used to do such things as making e-learning courses public, registering students in LMS and allowing faculty members and administrators to follow students' attendance in classes and their developmental processes (Cebeci, [10]; İnner, [24]). In this respect, LMSs include several software components which facilitate students' access to contents and which allow managing, following, reporting and distributing the interactions between the faculty member and students. With the help of these components, LMSs include various functions such as doing registration procedures for students, storing related information, following students' attendance in classes and their developments, conducting examinations, recording the results, and evaluating students' performances. All LMSs are expected to include these functions. As the basic function of LMSs is the management of students and trainers, most LMSs do not have the capability of creating content. For this reason, LMS developers either provide content-development tools or cooperate with other content developers to put forward solutions as a whole. On the other hand, Learning Management Systems provide educational content depending on several factors such as individuals who will take the related education; their personalities; the learning activity; study environments; learning capacity; and the policy to provide content (Duran, Önal, Kurtuluş, [16]).

This education program, which was designed to provide bachelor's diploma for students who own an associate diploma via vocational education, started to become gradually widespread in turkey. The purpose of this curriculum is to help students not only develop their efficacies regarding religion and but also become well-trained individuals. In order to plan and give this education in a way to avoid increasing the workload of institutions that give face-to-face education, e-learning management systems are now used. This learning management system is favored since it allows providing more students with the same-quality education. Students can prepare for their exams by following the courses via this learning management system throughout the week without any time restriction.

In addition, researchers examined the positive aspects of the system as well as the problems and difficulties experienced by faculty members giving lessons via e-learning management systems (Kaymakcan et.al., [27]; Otter et.al., [39]; Bilgiç, Doğan, [7]). These studies were conducted with faculty members using the e-learning management system, and they aimed at evaluating the approaches of trainers who knew and used the systems. In related literature, there is not much research carried out to investigate the use of e-learning management system designed to give education in different areas - for the undergraduate education of Theology students. The present study is thought to be important since it is expected to act as a guide for other state universities giving undergraduate education in e-learning platforms in Turkey.

\section{Literature Review}

Studies conducted by Educational Statistics National Center demonstrate that there is an increasing demand for acceptance of e-learning and students generally have positive views about learning experiences (Tabs, Waits, Lewis, [51]). In order to establish communication (e-mail, msn and so on) or social networks (Facebook, blogging), students prevailingly use digital and web tools in their lives Keller et 
al. [30], in their study, tried to predict the effects of such variables as age, gender, previous experiences regarding computer use and individual learning styles on students' acceptance of technology. In other studies, conducted by Kennedy et al. [31] in Australia, by Kvavik, [34] in USA and by Green et al. [19] in England, it was found that most students use e-learning platforms via their personal computers and smart phones which have access to the web. Kranzow [33] mentions an important question for faculty members who teach via e-learning systems: "How should e-learning courses be designed in a way to maximize students' motivation, performance and attendance as well as their levels of satisfaction?". Kraznow [33] emphasizes the importance of developing the feeling of cooperation in e-learning environments. On the other hand, in order to increase students' satisfaction, there is a need for better strategies to facilitate interaction with course contents besides establishing cooperative e-learning environments. Within such a cooperative community, there should be interaction between trainers and students as well as between students. Sher [48] points out that in e-learning systems, communication between trainers and students and between students is an important factor in students' satisfaction and in their learning. Strachota [49] focused on the influence of student-student interaction, student-trainer interaction, students' interaction with course contents and with technology on students' satisfaction in e-learning systems. In the study, Strachota [49] found that student-content interaction ranked first in students' satisfaction, which was followed by student-trainer interaction and student-technology interaction.

Palmer et al. [41] reported that students' ability to use technology easily plays an important role in satisfaction with e-learning. Another factor influential on students' satisfaction with e-learning is the extent to which they feel good in e-learning environments. In addition, according to Drennan et al. [15], one of the two important factors regarding students' satisfaction is related to their attitudes towards technology, and the second one is related to their independent and innovative learning styles.

\section{Hypothesis}

What are levels of mean scores of students attending Distance Education Theology Undergraduate Education Program regarding their attitudes towards e-learning?

Do students' attitude mean scores regarding e-learning management system differ depending on their gender, weekly Internet use time, years of computer use, their preferences of types of learning, their foreign languages, their foreign language proficiency levels, and their preferences of study and learning methods?

\section{Purpose}

The purpose of this study was to determine the gains and experiences acquired by students via e-learning system. In line with this purpose, the study focused on determining students' attitudes towards e-learning management system as well as on investigating whether their approaches to the system were significant with respect to certain variables.

\section{Method}

In the study, the descriptive survey model was used to examine the e-learning levels of students with respect to certain variables. Descriptive research method defines the current and past states of a situation being examined and explains these states with graphs and with the data collected (Gürsakal, [22]). In the study, for the analysis of the research data, the individual and relational model, one of general survey models, was used.

\section{Data Collection Tools}

For the purpose of collecting the research data, the scale of "Attitudes towards ICT skills and e-learning" developed by Haznedar [23] was used. The first part of the questionnaire applied to collect the research data included 12 items regarding the demographic backgrounds of the participants, their academic achievements, foreign language proficiency levels, their computer and Internet use, and their levels of knowledge about computer use and 20 items regarding the participants' attitudes towards e-learning.

\section{Sample}

In the study, the research sample was made up of 550 students attending the Distance Education Theology Undergraduate Education Program (DETUEP) at Dicle University in the academic year of 2013-2014. In the study, the participants were determined with the simple random sampling method, one of probability sampling methods. In this model, each member of the research group involved in the study has an equal chance of being selected. Students thought to be included in a study are selected from a list of students on random basis (Çepni, [13]: 46). In the study, for the research sample, the intention was to reach $70 \%$ of all the students.

Table 1 demonstrates the results of the analysis of the survey data regarding the demographic backgrounds of the students participating in the study. 
Table 1. Percentage and Frequency Distributions of the Participants with Respect to Their Demographic Backgrounds

\begin{tabular}{|c|c|c|c|}
\hline Variable & Property & f & $\%$ \\
\hline \multirow{2}{*}{ Gender } & Female & 152 & 39,90 \\
\hline & Male & 229 & 60,10 \\
\hline \multirow{4}{*}{ Weekly Internet Use time } & $0-7$ hours & 258 & 67,71 \\
\hline & $8-21$ hours & 88 & 23,10 \\
\hline & $22-35$ hours & 21 & 5,51 \\
\hline & More than 36 hours & 14 & 3,68 \\
\hline \multirow{5}{*}{ How many years do you use a computer? } & Less than a year & 24 & 6,30 \\
\hline & 1-3 Years & 98 & 25,72 \\
\hline & 4-5 Years & 69 & 18,11 \\
\hline & 6-7 Years & 60 & 15,75 \\
\hline & More than 7 years. & 130 & 34,12 \\
\hline \multirow{2}{*}{ Study Preference } & Individual & 188 & 49,34 \\
\hline & Group & 193 & 50,66 \\
\hline \multirow{3}{*}{ Learning Method } & E-Learning & 72 & 18,90 \\
\hline & Face-to-face education and e-learning together & 204 & 53,54 \\
\hline & Face-to-face education & 105 & 27,56 \\
\hline \multirow{5}{*}{ Mobil device selection } & Smart Cell Phone and Tablet PC or Notebook Computer & 103 & 27,03 \\
\hline & Tablet PC & 98 & 25,72 \\
\hline & Tablet and Notebook Computer & 128 & 33,60 \\
\hline & Notebook Computer & 12 & 3,15 \\
\hline & All & 40 & 10,50 \\
\hline \multirow{4}{*}{ Foreign Language Level } & Poor & 170 & 44,62 \\
\hline & Middle & 162 & 42,52 \\
\hline & Good & 46 & 12,07 \\
\hline & Very Good & 3 & 0,79 \\
\hline \multirow{2}{*}{ Language spoken } & Arabic & 189 & 49,61 \\
\hline & English & 192 & 50,39 \\
\hline \multirow{2}{*}{ Motivation Type } & Extrinsic Motivation & 131 & 34,38 \\
\hline & Intrinsic Motivation & 250 & 65,62 \\
\hline \multirow{3}{*}{ In what ways do you learn better? } & Visual & 228 & 59,84 \\
\hline & Aural & 121 & 31,76 \\
\hline & Tactual & 32 & 8,40 \\
\hline \multirow{5}{*}{$\begin{array}{l}\text { What do you use information } \\
\text { communication tools for? }\end{array}$} & Course related research. & 36 & 9,45 \\
\hline & $\begin{array}{l}\text { Course related research, commination, Homework, Online } \\
\text { Banking, Social networking, radio, TV, Newspaper }\end{array}$ & 79 & 20,73 \\
\hline & Course related research, Shopping, commination and other & 16 & 4,20 \\
\hline & Course related research, Shopping, commination & 39 & 10,24 \\
\hline & Course related research, commination, Film and other & 211 & 55,38 \\
\hline Total & & 381 & 100,0 \\
\hline
\end{tabular}

Of all the students participating in the study, $39,90 \%$ of them were female, and $60,10 \%$ of them were male. In addition, $67,71 \%$ of them used the Internet for 0 to 7 hours; $23,10 \%$ of them for 8 to 21 hours; $5,51 \%$ of them for 22 to 35 hours; and $3,68 \%$ of them used the Internet for 36 hours or longer. Also, $6,30 \%$ of them used a computer for less than a year; $25,72 \%$ of them for 1 to 3 years; $18,11 \%$ of them for 4 to 5 years; $15,75 \%$ of them for 6 to 7 years; and $34,12 \%$ of them for more than 7 years. Moreover, $27,03 \%$ of them used a smart phone, a Tablet PC or a Notebook computer; $25,72 \%$ of them used a Tablet PC; $33,60 \%$ of them used a Tablet PC and a Notebook computer; $3,15 \%$ of them used only a 
Notebook computer; and $10,5 \%$ of them used all the mobile devices. Of all the students participating in the study, 9,45\% of them used information communication devices to do research related to the lessons; $20,73 \%$ of them to do research related to the lessons, to communicate with others, to do homework, to do online banking, to share something in social networks, to listen to the radio, to watch TV channels, and to read newspapers; $4,20 \%$ of them to do research related to the lessons, to do shopping, to communicate and for other purposes; $10,24 \%$ of them to do research related to the lessons, to do shopping and to communicate with others; and $55,38 \%$ of them to do research related to the lessons, to communicate, to watch movies and for other purposes.

Among the participants, $49,61 \%$ of them spoke Arabic, and $50,39 \%$ of them spoke English. Of all the participants, $44,62 \%$ of them had a low level of proficiency in these languages; $42,52 \%$ of them had a moderate level of proficiency; $12,07 \%$ of them had a good level of proficiency; and $0,79 \%$ of them had a very good level of proficiency.

In addition, $49,34 \%$ of the students favored individual work, while $50,66 \%$ of them preferred group work. Also, $18,90 \%$ of them wanted to use e-learning management system, $53,54 \%$ of them wanted to use face-to-face education and e-learning management system together; and $27,56 \%$ of them wanted to take courses on face-to-face basis. Of all the students, $34,38 \%$ of them had an extrinsic type of motivation (awards given out of class, and other similar methods), while $65,62 \%$ of them had an intrinsic type of motivation (I myself wonder, I have the desire to develop myself). In the study, $59,84 \%$ of the participants reported that they would learn better via visual elements; $31,76 \%$ of them via auditory elements; and $8,40 \%$ of them reported that they would learn better via tactile elements.

\section{Distance Education Theology Undergraduate Education Program (DETUEP)}

Distance Education Theology Undergraduate Education Program (DETUEP) allows undergraduate graduates to take their lisans education without ruining their socio-economic conditions. Thanks to this program, it is possible to reach more students via the e-learning management system with the help of the expert academic staff in theology faculties. In addition, this system makes education independent of time and place as well as makes it possible for individuals to continue their education and to maintain their vocational lives.

\section{Findings}

This part presents the results of analyses regarding the participants' responses to the questionnaire applied in relation to e-learning. It was found that the attitude mean scores of the students taking theology undergraduate education with e-learning management system was at the level of "I partly agree" ( $\overline{\mathrm{X}}=2,87)$. In addition, t-test was conducted to reveal whether there was a significant difference between the attitude scores of the students regarding the e-learning management system with respect to their gender.

Table 2. t-test results for the students' attitude scores regarding e-learning management system with respect to their gender

\begin{tabular}{ccccccc}
\hline Gender & $\mathbf{n}$ & & Ss & Sd & t & $\mathbf{p}$ \\
\hline Female & 152 & 2,84 & 0,57 & 379 &, 936 &, 35 \\
Male & 229 & 2,89 & 0,59 & & & \\
\hline
\end{tabular}

The mean score for the female students taking theology undergraduate education with the e-learning management system was $\mathrm{Mean}_{\mathrm{F}}=2,84(\mathrm{Sd}=0,57)$, and the mean score of the male students was $\mathrm{Mean}_{\mathrm{M}}=2,89(\mathrm{Sd}=0.59)$. As a result, no significant difference was found between the mean scores $(t(379)=, 936 ; p>.05)$. In the study, for the purpose of determining whether there was a significant difference between the students' attitudes towards e-learning with respect to their weekly Internet use time, Kruskal Wallis test was applied.

Table 3. Kruskal Wallis test results regarding the students' attitudes towards e-learning management system with respect to their weekly Internet use time

\begin{tabular}{cccccc}
\hline $\begin{array}{c}\text { Weekly Internet Used } \\
\text { time }\end{array}$ & n & $\begin{array}{c}\text { Mean } \\
\text { Rank }\end{array}$ & df & Chi-Square & p \\
\hline 0-7 hours & 258 & 188,58 & 3 & 2,301 &, 512 \\
8 -21 hours & 88 & 166,74 & & & \\
22-35 hours & 21 & 211,36 & & \\
More than 3 hours & 14 & 200,65 & & \\
\hline
\end{tabular}

The results revealed no significant difference between the students' attitude mean scores regarding e-learning management system with respect to their weekly Internet use time ( $\mathrm{p}>.05)$. In the study, in order to determine whether there was a significant difference between the students' attitude mean scores in relation to their responses to the question of "How long have you been using a computer?", ANOVA was conducted.

Table 4. ANOVA results regarding the students' attitudes towards e-learning management system with respect to their years of computer use.

\begin{tabular}{cccccc}
\hline & KT & df & KO & F & P \\
\hline $\begin{array}{c}\text { Between } \\
\text { Groups }\end{array}$ &, 532 & 4 &, 133 &, 384 &, 820 \\
\hline $\begin{array}{c}\text { Within } \\
\text { Groups }\end{array}$ & 130,370 & 376 &, 347 & & \\
\hline Total & 130,903 & 380 & & & \\
\hline
\end{tabular}

In the study, no statistically significant difference was found between the students' levels of attitudes towards e-learning management system with respect to their years of computer use $\left(\mathrm{F}_{4-376}=133 ; \mathrm{p}=, 820\right)$. In addition, for the purpose of determining whether there was a significant difference between the attitude scores of the students regarding the e-learning management system with respect to their foreign languages, t-test was applied. 
Table 5. t-test results regarding the students' attitudes towards e-learning management system with respect to their foreign languages

\begin{tabular}{ccccccc}
\hline $\begin{array}{c}\text { Foreign } \\
\text { Language }\end{array}$ & $\mathbf{n}$ & $\overline{\mathrm{X}}$ & Ss & Sd & $\mathbf{t}$ & $\mathbf{p}$ \\
\hline Arabic & 189 & 2,88 & 0,61 & \multirow{2}{*}{379} & 2,42 &, 809 \\
English & 192 & 2,86 & 0,56 & & & \\
\hline
\end{tabular}

The mean score of the students regarding the e-learning management system who spoke Arabic as a foreign language was Mean $_{A}=2,88(\mathrm{Sd}=0,61)$ and that of the students who spoke English as a foreign language was Mean $_{E}=2,86$ $(\mathrm{Sd}=0,56)$. The results of the statistical analysis did not reveal any significant difference $(\mathrm{t}(379)=2,42 ; \mathrm{p}>.05)$. In order to determine whether there was a significant difference between the students' attitude mean scores regarding the e-learning management system in terms of their levels of foreign language proficiency, ANOVA was conducted. The level of "Very good" was not included in the analysis due to the low number of the students in this group.

Table 6. Results of ANOVA regarding the students' attitudes towards the e-learning management system with respect to their levels of foreign language proficiency

\begin{tabular}{cccccc}
\hline & KT & df & KO & F & P \\
\hline $\begin{array}{c}\text { Between } \\
\text { Groups }\end{array}$ &, 536 & 2 &, 268 &, 775 & ,462 \\
\hline $\begin{array}{c}\text { Within } \\
\text { Groups }\end{array}$ & 129,789 & 375 &, 346 & & \\
\hline Total & 130,325 & 377 & & & \\
\hline
\end{tabular}

In the study, no significant difference was found between the students' attitude mean scores regarding the e-learning management system with respect to their levels of foreign language proficiency $\left(\mathrm{F}_{2-374}=, 268 ; \mathrm{p}=, 476\right)$. In order to determine whether there was a significant difference between the students' attitude mean scores regarding their responses to the question of "In what ways do you learn better?", ANOVA was conducted.

Table 7. Results of ANOVA regarding the students' mean scores in relation to their attitudes towards e-learning management system in terms of their learning style preferences.

\begin{tabular}{cccccc}
\hline & KT & df & KO & F & P \\
\hline $\begin{array}{c}\text { Between } \\
\text { Groups }\end{array}$ & 1,043 & 2 &, 521 & 1,518 &, 221 \\
\hline $\begin{array}{c}\text { Within } \\
\text { Groups }\end{array}$ & 129,860 & 378 &, 344 & & \\
\hline Total & 130,903 & 380 & & & \\
\hline
\end{tabular}

In the study, no significant difference was found between the students' attitude mean scores regarding their visual, auditory and tactile preferences in relation to the question of "In what ways do you learn better?" $\left(\mathrm{F}_{2-378}=, 521 ; \mathrm{p}=, 221\right)$. In order to determine whether there was a significant difference between the learning management preferences of the students, ANOVA was conducted.

Table 8. Results of ANOVA regarding the students' mean scores in relation to their attitudes towards e-learning management systems in terms of their learning preferences.

\begin{tabular}{cccccc}
\hline & KT & df & KO & F & P \\
\hline $\begin{array}{c}\text { Between } \\
\text { Groups }\end{array}$ &, 104 & 2 &, 052 &, 151 &, 860 \\
\hline $\begin{array}{c}\text { Within } \\
\text { Groups }\end{array}$ & 130,798 & 378 &, 346 & & \\
\hline Total & 130,903 & 380 & & & \\
\hline
\end{tabular}

In the study, no significant difference was found between the students' e-learning attitude mean scores in terms of face-to-face, e-learning and hybrid learning (face-to-face and e-learning combined) $\left(\mathrm{F}_{2-378}=, 151 ; \mathrm{p}=, 860\right)$.

Table 9. t-test results regarding the students' attitude mean scores in relation to e-learning management system in terms of their study preferences

\begin{tabular}{ccccccc}
\hline $\begin{array}{c}\text { Method of } \\
\text { Studying }\end{array}$ & $\mathbf{n}$ & $\overline{\mathbf{X}}$ & Ss & Sd & $\mathbf{t}$ & $\mathbf{p}$ \\
\hline $\begin{array}{c}\text { Individual } \\
\text { Work }\end{array}$ & 188 & 2,80 & 0,61 & 379 & $-2,52$ &, 012 \\
$\begin{array}{c}\text { Group Work } \\
193\end{array}$ & 2,95 & 0,55 & & & \\
\hline
\end{tabular}

In the study, the attitude mean score of the students regarding the e-learning management system in terms of their study method (individual work or group work) was found significant $(\mathrm{t}(379)=-2,52 ; \mathrm{p}>.05)$. Accordingly, the attitude mean score of the students who preferred individual work was $\mathrm{Mean}_{\mathrm{IW}}=2,80(\mathrm{Sd}=0,61)$, while that of the students who preferred group work was $\mathrm{Mean}_{\mathrm{GW}}=2,95(\mathrm{Sd}=0.55)$. Depending on this result, it could be stated that the students who preferred individual work had better attitudes towards e-learning management system than those who preferred group work.

Table 10. t-test results regarding the students' attitude mean scores in relation to e-learning management system with respect to their learning motivations

\begin{tabular}{ccccccc}
\hline $\begin{array}{c}\text { Motivation of } \\
\text { Learning }\end{array}$ & $\mathbf{n}$ & $\overline{\mathbf{X}}$ & Ss & Sd & t & p \\
\hline External & 131 & 2,91 & 0,67 & 379 &, 844 &, 399 \\
Internal & 250 & 2,85 & 0,53 & & & \\
\hline
\end{tabular}

In the study, there was no significant difference $(\mathrm{t}(379)=, 844, \mathrm{p}>.05)$ between the learning motivations of the students (external motivation or internal motivation). The attitude mean score of the students who preferred external motivation was $\operatorname{Mean}_{\mathrm{E}}=2,91(\mathrm{Ss}=0,67)$, while that of the students who preferred internal motivation was $\operatorname{Mean}_{\mathrm{I}}=2,85$ $(\mathrm{Ss}=0.53)$. 
Table 11. Kruskal Wallis test results regarding the students' attitudes towards e-learning management system in terms of their purposes of using information and communication technologies.

\begin{tabular}{ccccc}
\hline Purpose of Using Information and Communication Technologies & $\mathrm{n}$ & Mean Rank & df & Chi-Square \\
\hline $\begin{array}{c}\text { Doing research in relation to lessons } \\
\text { Doing research in relation to lessons Communication, doing homework, online } \\
\text { banking, sharing something in social networks, listening to radio, watching TV } \\
\quad \text { channels, reading newspapers }\end{array}$ & 79 & 177,36 & 174,70 \\
$\begin{array}{c}\text { Doing research in relation to lessons, Shopping, communication and other } \\
\quad \text { Doing research in relation to lessons Shopping, communication }\end{array}$ & 16 & 196,06 & 3 & 4,862 \\
$\begin{array}{c}\text { Doing research in relation to lessons, Communication, watching movies and } \\
\text { other }\end{array}$ & 211 & 218,22 & 194,04 \\
\hline
\end{tabular}

In the study, no significant difference was found between the students' attitude mean scores regarding e-learning management system in terms of their purposes of using information and communication technologies $(p>.05)$. In order to determine whether there was a significant difference between the students' attitude mean scores regarding their preferences of mobile devices, ANOVA was conducted.

Table 12. t-test results regarding the students' attitude mean scores in relation to e-learning management system with respect to their preferences of mobile devices

\begin{tabular}{cccccc}
\hline & KT & df & KO & F & P \\
\hline $\begin{array}{c}\text { Between } \\
\text { Groups }\end{array}$ &, 979 & 4 &, 245 &, 709 &, 586 \\
\hline $\begin{array}{c}\text { Within } \\
\text { Groups }\end{array}$ & 129,923 & 376 &, 346 & & \\
\hline Total & 130,903 & 380 & & & \\
\hline
\end{tabular}

In the study, no significant difference was found between the students' attitude mean scores regarding e-learning management system in terms of their preferences of mobile devices $(p>05)$.

\section{Discussion and Conclusion}

This study was limited to 550 students attending Distance Education Theology Undergraduate Education Program at Dicle University in the academic year of 2013-2014. In the study, it was revealed that the theology undergraduate education students' means score regarding e-learning management system was at the level of "I Partly Agree" ( $\overline{\mathrm{X}}=2,87)$. The attitude mean score of the female students responding to the questionnaire was $\bar{X}=2,84$, while that of the male students was $\bar{X}=2,89$. The attitude mean scores of the two groups of students regarding e-learning management system were at the level of "I Partly Agree". The results of the statistical analysis did not reveal any significant difference between the two groups in terms of their gender. In a number of studies investigating attitudes towards e-learning revealed a significant difference between the participants' attitudes with respect to their gender in favor of the male participants (İşleyen et.al. [25]), yet recent research results have demonstrated that there is no significant difference between participants' attitudes in terms of gender (Yalman, [56]). The reason for lack of such a difference in recent studies could be the fact that female students using information and communication technologies did not have much knowledge about or interest in these technologies in the past.

One of the most important factors influential on attitudes towards e-learning management system is the level of knowledge about computer and Internet use. Studies conducted in the field demonstrated that students' low level of knowledge about devices and tools regarding information technologies increase their level of related anxiety (Dinçer et al. [14]; Chan et al. [11]; Thatcher et al. [53]). In the present study, no significant difference was found between the students' attitudes towards e-learning management system with respect to their weekly Internet use. In addition, it was also seen that there was no significant difference between the students' attitudes towards e-learning management system in terms of their years of computer use.

In the study, although the students participating in the study took courses via the e-learning management system, $53,54 \%$ of them preferred hybrid education, which combines both face-to-face learning and e-learning management system. In their study conducted on the productivity the theology undergraduate education program, Kaymakcan and colleagues [27] reported that not only the students taking education with the traditional method but also those attending the theology undergraduate education program preferred education given with the traditional method. In addition, statistical analysis of the participants' responses revealed that there was no significant difference regarding their attitudes towards e-learning management system in terms of their preferences of face-to-face, e-learning or hybrid learning. The results of the statistical analysis regarding the participants' responses to the questionnaire revealed that there was no significant difference between the students' attitudes towards e-learning management system in terms of their preferences of face-to-face learning, e-learning or hybrid learning. The reason for this result could be the fact that the faculty members teaching courses at universities combine face-to-face learning method and e-learning platforms as a support to education (Akkuş, Keskin [2]; Orhan et al. [38]; Seng, Mohamad, [47]). In one study conducted by Ünsal [55] to examine the influence of hybrid learning on students' achievement and motivation, no 
significant difference was found between the achievement scores of the students taking courses on face-to-face basis and those of the students taking education on the basis of hybrid learning. In addition, the present study did not reveal any statistically significant difference between the students' motivation types (internal and external) they favored as a learning method.

The mobile devices that students taking theology undergraduate education via e-learning management system prefer to log in or use the system could have influence on the usability of the system (Popovici, Mironov [43]). Liaw et al. [37] state that students' approaches to e-learning environments are more important than the technology itself used for these environments. In this respect, the design and usability of e-learning environments are important. In one study examining what e-learning is and how and by whom it should be designed, Khan, Joshi [32] reported that it is necessary to analyze students who will take education via e-learning platforms before structuring such systems. In the present study, no statistically significant difference was found between the students' preferences of technological devices they used for the e-learning management system. The students' responses to the questionnaire revealed that they were able to use more than one mobile device together. Kaymakcan and colleagues [28], in their study conducted with students from six different universities giving theology undergraduate education in Turkey (Atatürk, Dokuz Eylül, Firat, İnönü, İstanbul and Sakarya), found that the most productive learning environments were live lessons and e-books used as an educational material on the system. In addition, Internet platforms and PowerPoint presentations were not found productive as learning environments.

The spread of the Internet has gradually increased the use of e-learning systems (Sun et al. [50]). Users prefer e-learning platforms because these platforms can now support several languages. For this reason, the language used in the design of e-learning systems is important. In the present study, no significant difference was found in relation to the students' foreign languages (Arabic and English). This result could be explained by the fact that the system used in the study had an effective and functional design totally appropriate to the students' profile (Zanjani et al. [58]; Rothwell, Kazanas, [46]; Rakap, [44]). In addition, the present study did not reveal any significant difference regarding the students' levels of foreign language proficiency.

In the study, no significant difference was found in relation to the students' visual, auditory and tactile preferences of learning methods. The related results in the study revealed that there were no significant differences between the students in terms of such variables as gender, weekly Internet use, years of computer use, preference of learning method and preference of mobile devices. The students' responses to the questionnaire revealed a significant difference only with respect to their study methods (individual work or group work). The results of the analysis demonstrated that the students who preferred individual work were better in terms of their levels of satisfaction with e-learning than those who preferred group work. This significant difference could be explained by the fact that e-learning environments are regarded as individualized learning environments and that achievement tests conducted via the system include individual contents (Gülbahar, [20]; Güngör, Aşkar, [21]).

\section{REFERENCES}

[1] Ally M. "Foundations of Educational Theory for Online Learning". The Theory and Practice in Online Learning, $16-$ 45., 2008 .

[2] Akkuş, M., \& Keskin, Y. HARMANLANMIŞ ÖĞRENME MODELIYLE İLGILİ ÖĞRENCİ TUTUMLARININ INCELENMESI. Journal of Research in Education and Teaching. Mayıs 2016 Cilt:5 Sayı:2 Makale No: 33 ISSN: 2146-9199.9., 2016.

[3] American Distance Education Consortium (ADEC). (n.d.). Quality framework for online education. Lincoln, NE: Author. Retrieved December 28, 2008, from http://www.adec.edu/earmyu/ SLOANC?41.html

[4] Aoki, K., Pogroszewski, D. Virtual university reference model: A guide to delivering education and support services to the distance learner. Online journal of distance learning administration, 1(3)., 1998.

[5] Arbaugh, J. B. Virtual classroom characteristics and student satisfaction with internet-based MBA courses. Journal of management education, 24(1), 32-54., 2000.

[6] Benković, S., Dobrota, M. Application of Teaching Methods and Techniques at Serbian Universities: Progress Over Time. Management, 1820-0222, 63., 2012. doi:10.7595/management. fon.2012.0007

[7] Bilgiç, H. G., Doğan, D., Seferoğlu, S. S., \& Deklarasyonu, T. Gelişen ve değişen üniversiteler ve Türkiye'de yüksek öğretimde çevrimiçi öğretimin durumu. Uluslararası Yükseköğretim Kongresi. Yeni Yönelişler ve Sorunlar, 27-29., 2011.

[8] Bolliger, D. U., Martindale, T. Key factors for determining student satisfaction in online courses. International Journal on E-Learning, 3(1), 61-67., 2004.

[9] Bradford, G., Wyatt, S. Online learning and student satisfaction: Academic standing, ethnicity and their influence on facilitated learning, engagement, and information fluency. The Internet and Higher Education, 13(3), 108-114., 2010.

[10] Cebeci, Z. Öğrenim Yönetim-İçerik Sistemlerine Giriş. 9. Türkiye'de Internet Konferans1 INET-TR 2003, 11-13 Aralık 2003, istanbul.

[11] Chan, K. W., Wong, K. Y. A., \& Lo, S. C. E. Relational analysis of intrinsic motivation, achievement goals, learning strategies and academic achievement for Hong Kong secondary students. The Asia-Pacific Education Researcher, 21(2), 230-243., 2012. 
[12] Cheng, Y. M. Antecedents and consequences of e-learning acceptance. Information Systems Journal, 21(3), 269-299., 2011.

[13] Çepni, S. Araştırma ve Proje Çalışmalarına Giriş, 5.Baskı, Celepler Matbaacilık, Trabzon. 2010.

[14] Dinçer, S. ve Yeşilpınar-Uyar, M. (2015). E-öğrenme sistemlerinin kullanımı sürecinde karşılaşılan sınıf yönetimi ile ilişkili sorunlar ve çözüm önerileri. Kuram ve Uygulamada Eğitim Yönetimi, 21(4), 453-470. doi: $10.14527 /$ kuey.2015.017

[15] Drennan, J., Kennedy, J., Pisarski, A. Factors affecting student attitudes toward flexible online learning in management education. The Journal of Educational Research, 98(6), 331-338., 2005.

[16] Duran, N., Önal, A., Kurtuluş, C. E-ÖĞRENME ve KURUMSAL EĞITIMIME YENI YAKLAȘIM ÖĞRENIM YÖNETIMM SİSTEMLERİ. 2006.

[17] Engelbrecht, E. Adapting to changing expectations: Post-graduate students' experience of an e-learning tax program. Computers \& Education, 45(2), 217-229., 2005. http://dx.doi.org/10.1016/j.compedu.2004.08.001.

[18] Gibson, J. W., Tesone, D. V., Hodgetts, R. M., Blackwell, C. $\mathrm{W}$. The human dimension of online education: Cyberstudents speak out. In Professional Communication Conference, 2001. IPCC 2001. Proceedings. IEEE International (pp. 367-378). IEEE. 2001

[19] Green, H., Hannon, C. Their space: Education for a digital generation. 2007.

[20] Gülbahar, Y. E-öğrenme. PegemA Yayıncılık, 1. Bask1, Ankara. 2009.

[21] Güngör, C., Aşkar, P. E-öğrenmenin ve bilişsel stilin öğrenci başarısı ve internet öz yeterlik algısı üzerindeki etkisi. Hacettepe Üniversitesi Eğitim Fakültesi Dergisi, 27, 116-125., 2004.

[22] Gürsakal, N. (2008). Betimsel İstatistik, Minitab SPSS Statistica Excel Uygulamal1. Dora Yayınc1l1k, Bursa.

[23] Haznedar, Ö. “Üniversite Öğrencilerinin Bilgi Ve İletişim Teknolojileri Becerilerinin Ve E-Öğrenmeye Yönelik Tutumlarının Farklı Değişkenler Açısından İncelenmesi”. (Yayınlanmış yüksek lisans tezi). Dokuz Eylül Üniversitesi, Eğitim Bilimleri Enstitüsü, İzmir. 2012.

[24] İnner, B. Öğrenme Yönetim Sisteminin (Moodle) Örgün Öğretim Laboratuvar Uygulamalarında Kullanılması. Ulusal Teknik Eğitim, Mühendislik ve Eğitim Bilimleri Genç Araştırmacılar Sempozyumu UMES 2007. 20-22 Haziran 2007, Kocaeli Üniversitesi, İzmit.

[25] İşleyen, F., Bozkurt, S., Neşe, Z. A. Y. Tıp Öğrencilerinin Eğitimde İnternet Kullanımı ve E-öğrenmeye İlişkin Düşünceleri. V. Ulasal Tıp Kongresi, Antalya. 2008.

[26] KABA, A. U., GÜNEŞ, A., ALTINTAŞ, T. E-öğrenmede destek hizmetlerinin öğrenen memnuniyetine etkisi. Aydın Üniversitesi Dergisi. 2012.

[27] KAYMAKCAN, R., MEYDAN, H., TELLİ, A., \& CEVHERLI, K. İlahiyat Lisans Tamamlama Programının Verimliliği Üzerine Olgusal Bir Araştırma. Hitit Üniversitesi İlahiyat Fakültesi Dergisi, 13(26), 43-62., 2015.
[28] Kaymakcan, R., Meydan, H., Telli, A., \& Cevherli, K. Paydaşlarına Göre İlahiyat Lisans Tamamlama (İLITAM) Programının Değerlendirilmesi. Değerler Eğitimi Dergisi, 71-110., 2013.

[29] Kaynama, S. A., Keesling, G. Development of a Web-based Internet marketing course. Journal of Marketing Education, 22(2), 84-89., 2000. doi:10.1177/0273475300222002

[30] Keller, C., Cernerud, L. Students' perceptions of e-learning in university education. Journal of Educational Media, 27(1-2), 55-67., 2002.

[31] Kennedy, G. E., Judd, T. S., Churchward, A., Gray, K., Krause, K. L. First year students' experiences with technology: Are they really digital natives. Australasian journal of educational technology, 24(1), 108-122., 2008.

[32] Khan, B. H., Joshi, V. E-Learning Who, What and How?. Journal of Creative Communications, 1(1), 61-74., 2006.

[33] Kranzow, J. Faculty leadership in online education: Structuring courses to impact student satisfaction and persistence. Journal of Online Learning and Teaching, 9(1), 131., 2013.

[34] Kvavik, R. B. Convenience, communications, and control: How students use technology. Educating the net generation, 1, 7-1., 2005.

[35] Lee, Y. H., Hsieh, Y. C., Ma, C. Y. A model of organizational employees'e-learning systems acceptance. Knowledge-based systems, 24(3), 355-366., 2011

[36] Liaw, S. S. Investigating students' perceived satisfaction, behavioral intention, and effectiveness of e-learning: A case study of the Blackboard system. Computers \& Education, 51(2), 864-873., 2008. doi:10.1016/j.compedu.2007.09.005

[37] Liaw, S. S., Huang, H. M., Chen, G. D. Surveying instructor and learner attitudes toward e-learning. Computers \& Education, 49(4), 1066-1080., 2007.

[38] ORHAN, F., ALTUN, A. S., KABLAN, Z. Karma Ögrenme (Blended Learning) Yöntemine Dayalı Bir Uygulama ve Ögrenci Görüsleri: Yıldız Teknik Üniversitesi Örnegi, IV. Uluslararası Egitim Teknolojileri Sempozyumu, 24-26 Kasım 2004, Sakarya, Türkiye. 2004.

[39] Otter, R., Seipel, S., Graeff, T., Alexander, B., Boraiko, C., Gray, J., Petersen, K. \& Sadler, K. (2013). Comparing student and faculty perceptions of online and traditional courses. The Internet and Higher Education, 19, 27-35.

[40] Paechter, M., Maier, B., Macher, D. Students' expectations of, and experiences in e-learning: Their relation to learning achievements and course satisfaction. Computers \& education, 54(1), 222-229., 2010. http://dx.doi.org/10.1016/ j.compedu.2009.08.005.

[41] Palmer, S. R., Holt, D. M. Examining student satisfaction with wholly online learning. Journal of computer assisted learning, 25(2), 101-113., 2009. doi: 10.1111/j.1365-2729.2008.00294.x

[42] Peltier, J. W., Schibrowsky, J. A., Drago, W. The interdependence of the factors influencing the perceived quality of the online learning experience: A causal model. Journal of Marketing Education, 29(2), 140-153., 2007.

[43] Popovici, A., \& Mironov, C. Students' Perception on Using 
eLearning Technologies. Procedia-Social and Behavioral Sciences, 180, 1514-1519., 2015.

[44] Rakap, S. Impacts of learning styles and computer skills on adult students' learning online. TOJET: The Turkish Online Journal of Educational Technology, 9(2)., 2010.

[45] Roberts, T. G., Irani, T. A., Telg, R. W., Lundy, L. K. The development of an instrument to evaluate distance education courses using student attitudes. The American Journal of Distance Education, 19(1), 51-64., 2005.

[46] Rothwell, W. J., Kazanas, H. C. Mastering the instructional design process: A systematic approach. John Wiley \& Sons., 2011.

[47] SENG, L., MOHAMAD, F., S. Online Learning Is it Meant for Science Courses? Internet and Higher Education, 5, 109-118., 2002

[48] Sher, A. Assessing the relationship of student-instructor and student-student interaction to student learning and satisfaction in web-based online learning environment. Journal of Interactive Online Learning, 8(2), 102-120., 2009.

[49] Strachota, E. M. Student satisfaction in online courses: An analysis of the impact of learner-content, learner-instructor, learner-learner and learner-teacher interaction. Dissertation Abstracts International, 64(08), 2746., 2003.

[50] Sun, P. C., Tsai, R. J., Finger, G., Chen, Y. Y., Yeh, D. What drives a successful e-Learning? An empirical investigation of the critical factors influencing learner satisfaction. Computers \& education, 50(4), 1183-1202., 2008.
[51] Tabs, E. D., Waits, T., Lewis, L. Distance education at degree-granting postsecondary institutions: 2000-2001. Washington, DC: US Department of Education., 2003.

[52] Tekinarslan, E. Attitudes of Turkish Distance Learners Toward Internet Based Learning: An Investigation Depending on Demographical Characteristics. Turkish Online Journal of Distance Education, 9(1)., 2008.

[53] Thatcher, J. B., Loughry, M. L., Lim, J., McKnight, D. H. Internet anxiety: An empirical study of the effects of personality, beliefs, and social support. Information \& Management (44), 353-363., 2007.

[54] Thorpe, M. Learner support: A new model for online teaching and learning. In Paper to the 20th ICDE World Conference, Düsseldorf., 2001, April.

[55] ÜNSAL, H. HARMANLANMIŞ ÖĞRENMENIN BAŞARI VE MOTIVASYONA ETKİSI. Türk Eğitim Bilimleri Dergisi, 10(1)., 2012

[56] YALMAN, M. EĞİTIM FAKÜLTESİ ÖĞRENCILLRININ BİLGISAYAR DESTEKLİ UZAKTAN EĞITTIM SISTEMI (MOODLE) MEMNUNIYET DÜZEYLERİ. Electronic Turkish Studies, 8(8)., 2013.

[57] YALMAN, M., \& KUTLUCA, T. The Design, Application and Evaluation of a Web-Based E-Learning System (MOODLE). Journal of Turkish Science Education, 11(1)., 2014.

[58] Zanjani, N., Edwards, S. L., Nykvist, S., \& Geva, S. LMS Acceptance: The Instructor Role. The Asia-Pacific Education Researcher, 1-8., 2016. 